\title{
PENGARUH RIWAYAT POLA ASUH TERHADAP KARIES GIGI BALITA
}

\author{
(INFLUENCE OF PARENTING HISTORY TOWARDS DENTAL \\ CARIES OF TOOLDLER)
}

\author{
Ristya Widi Endah Yani*, Darmawan Setijanto**, Seno Pradopo***, Destyka Fridiana**** \\ Departemen Ilmu Kesehatan Gigi dan Mulut Masyarakat/Pencegahan \\ Fakultas Kedokteran Gigi, Universitas Jember \\ Departemen Ilmu Kesehatan Gigi dan Mulut Masyarakat/Pencegahan \\ Departemen Ilmu Kedokteran Gigi Anak \\ Fakultas Kedokteran Gigi, Universitas Airlangga \\ Dokter Gigi Puskesmas Tajinan, Malang, Jawa Timur \\ J1. Kalimantan 37 Jember \\ E-mail: ristya_widi@yahoo.com
}

\begin{abstract}
Parenting history affects dental caries of toddlers (3-5 years), which it includes history of evening milk bottle drinking and teeth cleaning behavior by mother. Caries in infants and children is associated with baby's diet. Research on children who were fed in evening had more 5.1 times the risk of caries developing than children who did not eat in evening. The children still need parents to help brushing their teeth, this has been shown in associated with the development of caries toddlers. Regarding to the previous research, the author determines to investigate whether there is an influence of bottle milk drinking in evening and behavior of teeth cleaning by the mother against dental caries of toddlers. Analytic observational study was performed and the cross sectional approach. The research population was toddlers in Puskesmas Ambulu Jember (461 children). The sample was taken by using simple random sampling consisted of 102 children. The independent variable was the history of bottle milk drinking in evening and behavior of teeth cleaning (0-2 years) which conducted by mother. The dependent variable was dental caries of toddlers using pufa index (pulpitis, ulcerative, fistula, abscess). Data was analyzed by using multiple linear regression. The results showed that the influence of drinking milk bottle habit to dental caries toddlers had p-value 0.00 and behavior of the mother cleaning toddler teeth against dental caries toddlers had p-value 0.00 . In conclusion, there was an influence history of evening bottle milk drinking and teeth cleaning behavior which was conducted by mother against dental caries of toddlers.
\end{abstract}

Key words: milk bottle, tooth cleaning behavior, dental caries

\begin{abstract}
Abstrak
Riwayat pola asuh sangat mempengaruhi karies gigi balita (3-5 tahun), yang mana pola asuh meliputi riwayat minum susu botol malam hari dan perilaku membersihkan gigi oleh ibu. Penelitian pada anak-anak yang diberi makan pada malam hari memiliki risiko 5,1 kali untuk berkembangnya karies dibandingkan dengan anak yang tidak makan di malam hari. Balita masih membutuhkan orang tua dalam membantu menyikat giginya, hal ini telah terbukti berhubungan dengan perkembangan karies balita. Tujuan penelitian ini untuk mengetahui pengaruh riwayat minum susu botol malam hari dan perilaku membersihkan gigi oleh ibu terhadap karies gigi balita. Metode penelitian adalah observasional analitik dengan pendekatan cross sectional. Populasi penelitian adalah balita (3-5 tahun) di wilayah kerja Puskesmas Ambulu Kabupaten Jember yang berjumlah 461 balita. Sampel diambil secara simple random sebanyak 102 balita. Variabel independen adalah riwayat minum susu botol malam hari dan perilaku membersihkan gigi oleh ibu pada waktu balita berusia 0-2 tahun. Variabel dependen adalah karies gigi balita yang diukur dengan indeks pufa (pulpitis, ulceratif, fistula, abses). Data dianalisis dengan uji regresi linier ganda. Hasil penelitian menunjukkan terdapat pengaruh kebiasaan minum susu botol terhadap karies gigi balita $(\mathrm{p}=0,00)$ dan perilaku ibu membersihkan gigi balita terhadap karies gigi balita $(\mathrm{p}=0,00)$. Sebagai kesimpulan, terdapat pengaruh riwayat minum susu botol malam hari dan perilaku membersihkan gigi oleh ibu terhadap karies gigi balita.
\end{abstract}

Key words: susu botol, perilaku membersihkan gigi, karies gigi 


\section{PENDAHULUAN}

Riwayat pola asuh terdiri atas kebiasaan minum susu botol pada malam hari dan perilaku pembersihan gigi oleh ibu atau pengasuh. ${ }^{1}$ Karies pada bayi dan anak-anak berkaitan dengan pola makan bayi. Secara khusus, pola makan pada siang hari dan minum susu botol malam hari berpengaruh terhadap karies gigi. ${ }^{2}$ Susu yang sering berkontak lama dengan enamel gigi telah terbukti menyebabkan kondisi asidiogenik dan pelunakan enamel. Kondisi ini karena produksi air liur yang kurang pada malam hari dan jumlah laktosa lebih tinggi dalam air liur dan plak gigi yang lebih lama dibanding pada siang hari. Dengan demikian, keseimbangan bergeser ke arah demineralisasi. ${ }^{3}$ Anak-anak yang diberi makan pada malam hari memiliki 5,1 kali risiko untuk memiliki karies dibandingkan anak yang tidak makan di malam hari. ${ }^{4}$ Hasil penelitian Prashanth dkk. pada 412 anak yang minum dari botol di malam hari mempunyai persentase karies lebih tinggi $(40,7 \%)$ dibandingkan dengan kelompok anak yang tidak memiliki kebiasaan minum susu botol malam hari. ${ }^{5}$ Penelitian Subramaniam dan Prashanth menunjukkan dari 1537 balita usia 8-48 bulan yang menggunakan susu botol sewaktu tidur pada malam hari memperlihatkan karies gigi yang lebih tinggi dibandingkan balita yang tidak minum susu botol pada malam hari. ${ }^{6}$

Balita tidak memiliki kemampuan untuk membersihkan giginya sendiri secara efektif, sehingga orang tua dianjurkan untuk membantu membersihkan gigi balitanya setidaknya sampai mereka mencapai usia sekolah. Orang tua terutama ibu memegang peran kunci dalam memelihara kesehatan balita. Ibu tidak hanya berperan sebagai fasilitator dalam membersihkan mulut balita, tapi juga sebagai inisiator perilaku menjaga kesehatan mulut balita. ${ }^{5,7}$ Ibu sebagai pengasuh utama harus dapat membantu merawat kesehatan mulut balita. Perilaku orang tua menentukan status kesehatan gigi dan mulut balita, karena itu orang tua harus mempunyai pengetahu an yang cukup tentang pencegahan penyakit gigi dan mulut, hal ini harus dilakukan selama dua tahun pertama kehidupan balita yang merupakan periode yang paling penting. ${ }^{8}$ Studi yang dilakukan Maharani dan Raharjo di kota satelit di Indonesia dengan 152 sampel ibu dan anak menunjukkan $70 \%$ anak menderita karies dan lebih dari 50\% ibuibu memiliki pengetahuan dan perilaku rendah terhadap kesehatan gigi, dengan fakta yang terungkap di antaranya: (1) tidak pernah memeriksa gigi anakanak mereka, (2) mulai membersihkan gigi anak mereka setelah usia anak lebih dari 1 tahun, (3) tidak mengetahui bahwa karies adalah penyakit menular, (4) sering menggunakan peralatan makan dan minum yang sama dengan anak-anak mereka, dan (5) menganggap gigi sulung tidak penting karena akan diganti dengan gigi tetap. ${ }^{9}$

\section{BAHAN DAN METODE}

Jenis penelitian adalah observasional analitik dengan pendekatan cross sectional. Sampel adalah balita usia 3-5 tahun yang berjumlah 102 anak di wilayah kerja Puskesmas Ambulu Kabupaten Jember yang diambil secara simple random. Variabel independen adalah riwayat minum susu botol malam hari dan riwayat perilaku membersihkan gigi oleh ibu pada waktu balita berusia 0-2 tahun pengumpulan data menggunakan kuesioner. Variabel dependen adalah karies gigi balita yang diukur dengan indeks pufa (pulpitis, ulceratif, fistula, abses). Data dianalisis dengan uji regresi linier ganda

\section{HASIL}

Nilai minimum variabel riwayat kebiasaan minum susu botol malam hari adalah 1,75 , nilai maksimum 3,62 dan rata-rata adalah $2,84 \pm 0,49$. Nilai minimum variabel riwayat perilaku membersihkan gigi balita oleh ibu adalah 2,00, nilai maksimum 3,62 dan rata-rata $2,98 \pm 0,41$. Nilai minimum variabel karies gigi adalah 0,00 , nilai maksimum 15,00 dan rata-rata adalah $5,57, \pm 3,95$ dan varians 15,57 (Tabel 1).

Tabel 1. Nilai rata-rata mean, standar deviasi dan varian variabel

\begin{tabular}{|c|c|c|c|c|c|c|}
\hline Variabel & $\mathrm{n}$ & Minimum & Maksimum & Rata-rata & $\begin{array}{c}\text { Standard } \\
\text { deviasi }\end{array}$ & Varians \\
\hline $\begin{array}{l}\text { Riwayat kebiasaan minum susu } \\
\text { botol malam hari }\end{array}$ & 102 & 1,75 & 3,62 & 2,84 & 0,49 & 0,24 \\
\hline $\begin{array}{l}\text { Riwayat perilaku membersihkan } \\
\text { gigi balita oleh ibu }\end{array}$ & 102 & 2,00 & 3,62 & 2,98 & 0,41 & 0,17 \\
\hline Karies gigi & 102 & 0,00 & 15,00 & 5,57 & 3,95 & 15,57 \\
\hline
\end{tabular}


Hasil analisis regresi linier ganda menunjukkan bahwa variabel riwayat minum susu botol malam hari pada waktu balita berusia 0-2 tahun berpengaruh terhadap karies gigi $(p=0,00)$ dan variabel riwayat perilaku membersihkan gigi oleh ibu pada waktu balita berusia $0-2$ tahun berpengaruh terhadap karies gigi $(\mathrm{p}=0,00)($ Tabel 2$)$.

Tabel 2. Uji regresi linier ganda variabel riwayat minum susu botol malam hari dan perilaku membersihkan gigi oleh ibu terhadap karies gigi balita

\begin{tabular}{lc}
\hline Variabel & p-value \\
\hline Constant & 0,00 \\
Kebiasaan minum susu botol & 0,00 \\
Perilaku ibu membersihkan gigi balita & 0,00 \\
\hline
\end{tabular}

\section{PEMBAHASAN}

Hasil penelitian menunjukkan terdapat pengaruh riwayat pola asuh terhadap karies gigi balita. Riwayat pola asuh terdiri atas kebiasaan minum susu botol pada malam hari dan perilaku pembersihan gigi oleh ibu. ${ }^{1}$ Riwayat kebiasaan minum susu botol pada malam hari saat balita berusia 0-2 tahun berpengaruh terhadap karies giginya. Susu botol mengandung karbohidrat yang difermentasi. Penggunaan dot botol yang mengandung gula secara terus menerus pada balita terutama pada saat tidur malam hari menjadikannya tempat ideal untuk memproduksi asam oleh bakteri penyebab karies gigi. ${ }^{10,11}$

Pemberian susu botol berbeda dengan ASI, ketika bayi minum ASI, puting ditarik kedalam mulut dan air susu dilepaskan langsung ke dalam tenggorokan, sedangkan jika menggunakan susu botol, air susu yang keluar akan terperangkap di mulut dan sekitar gigi. Terdapat hubungan paparan karbohidrat dan karies, baik waktu makan dan saat tidur.Selama periode ini, saliva berkurang dan pembersihan karbohidrat di gigi tidak maksimal, sehingga memungkinkan fermentasi oleh bakteri. Meningkatnya jumlah bakteri Streptokokus mutans dalam plak gigi dan saliva dapat meningkatkan risiko karies gigi balita. Hal ini disebabkan karena terjadi penurunan aliran saliva dan refleks menelan saat tidur yang memungkinkan karbohidrat cair untuk tetap tinggal di mulut sekitar gigi. Penempatan lidah ke depan melindungi gigi anterior rahang bawah dari karies dan memungkinkan perkembangan ECC.5,10,12,14 Frekuensi dan lamanya penggunaan susu botol di siang dan malam hari dan kebiasaan makan yang salah adalah penyebab paling umum yang mempengaruhi perkembangan karies rampan meskipun bukan satu-satunya faktor etiologi. ${ }^{15,16}$

Riwayat perilaku membersihkan gigi oleh ibu pada waktu balita berusia 0-2 tahun juga berpengaruh terhadap karies giginya, hal ini sesuai dengan penelitian Subramaniam and Prashanth, yang menunjukkan hasil bahwa balita yang membersihkan gigi sendiri memiliki karies lebih tinggi dibandingkan balita yang melakukan pembersihan gigi dengan bantuan dan pengawasan orang tua, hal ini menunjukkan pentingnya peran orang tua atau pengasuh dalam melakukan pembersihan gigi balita. ${ }^{13}$

Pembersihan gigi dan mulut balita harus dimulai sejak dini dan menyikat gigi direkomendasikan ketika gigi pertama erupsi, setidaknya sekali sehari sampai usia 2 tahun dan selanjutnya dua kali sehari. ${ }^{17}$ Usia balita masih membutuhkan orang tua untuk membantu menyikat gigi anaknya di samping menyikat giginya sendiri, hal ini telah terbukti berhubungan dengan perkembangan karies balita. ${ }^{18}$ Balita tidak memiliki kemampuan untuk membersihkan giginya sendiri secara efektif, sehingga orang tua dianjurkan untuk membantu membersihkan gigi balitanya setidaknya sampai mereka mencapai usia sekolah. Orang tua terutama ibu memegang peran kunci dalam memelihara kesehatan balita.Ibu tidak hanya berperan sebagai fasilitator dalam membersihkan mulut balita, tapi juga sebagai inisiator perilaku menjaga kesehatan mulut balita. ${ }^{5,7,19} \mathrm{Ibu}$ sebagai pengasuh utama harus dapat membantu dalam merawat kesehatan mulut balita. Perilaku orang tua menentukan status kesehatan gigi dan mulut balita, karena itu orang tua harus cukup pengetahuan tentang pencegahan penyakit gigi dan mulut, hal ini harus dilakukan selama dua tahun pertama kehidupan balita yang merupakan periode yang paling penting. ${ }^{8}$ Beberapa faktor seperti pendidikan, pekerjaan, usia, pengetahuan saat ini, sikap dan perilaku ibu dapat memberikan wawasan tentang kesehatan gigi dan mulut balita secara tidak langsung. Hasil penelitian menunjukkan bahwa frekuensi ibu dalam menyikat gigi secara signifikan berhubungan dengan frekuensi menyikat gigi balita. Keterampilan menyikat gigi ibu dapat mempengaruhi frekuensi dan kualitas menyikat gigi balita, karena balita belajar dari perilaku orang tua (ibu). ${ }^{20}$

Balita umumnya menghabiskan sebagian besar waktu mereka dengan orang tua terutama ibu. Kebiasaan makan dan perilaku sehat yang diterapkan di rumah tergantung pada pengetahuan dan perilaku orang tua. Sikap ibu yang positif akan berhubungan dengan menyikat gigi yang benar, penurunan lesi karies dan pemeliharaan kesehatan mulut balita. Balita lebih santai dan berani untuk melakukan perawatan gigi jika ibu mereka memiliki sikap positif terhadap perawatan dan pengobatan gigi, bahkan disebutkan bahwa balita yang memiliki hubungan (komunikasi) dalam keluarga yang baik memiliki tingkat kerusakan gigi yang rendah dan kebersihan mu- 
lut yang baik. ${ }^{21,22}$ Beberapa penelitian melaporkan bahwa sikap orang tua yang kurang tepat terhadap kesehatan gigi dan mulut berhubungan dengan peningkatan prevalensi karies. Tanpa pengetahuan kesehatan gigi, misalnya faktor risikor karies, pentingnya gigi sulung dan pemeliharaan gigi dan mulut, sulit untuk menerapkan strategi yang efektif terhadap pencegahan penyakit gigi dan mulut. Pengetahuan orangtua dan sikap positif terhadap perawatan gigi berperan penting dalam pencegahan penyakit gigi dan mulut balita. ${ }^{23}$

Sebagai kesimpulan, terdapat pengaruh riwayat pola asuh ibu terhadap karies gigi balita. Balita yang tidak memiliki riwayat minum susu botol pada malam hari (usia 0-2 tahun) dan adanya peran ibu dalam membantu membersihkan gigi balita akan mengurangi karies gigi balita.

\section{Daftar Pustaka}

1. Hooley M, Skouteris H, Boganin C, Satur J, Kilpatrick N. Parental Influence and the Development of Dental Caries in Children Aged 0-6 Years: A Systematic Review of the Literature. Journal of Dentistry 2012; 40: 873-85.

2. Sowole CA, Sote EO. Breast Feeding, Bottle Feeding And Caries Experience In Children Aged 6 Months To 5 Years In Lagos State, Nigeria. African Journal of oral Health 2006; 2(1,2): 43-56.

3. Colak H, Dulgergil CT, Dalli M, Hamidi MM. Early Childhood Caries Update: A Review of Causes, Diagnoses, and Treatments. J Nat Sci Biol Med 2013; 4(1): 29-38.

4. Retnakumari N, Cyriac Gibi. Childhood caries as influenced by maternal and child characteristics in pre-school children of Kerala-an epidemiological study. Contemp Clin Dent 2012; 3(1): 2-8.

5. Prakash P, Subramaniam P, Durgesh BH, Konde S. Prevalence of Early Childhood Caries and Associated Risk Factors in Preschool Children of Urban Bangalore India: A Cross-Sectional Study. European Journal of Dentistry 2012; 6(2): 141-52.

6. Prakasha SS, Gupta VGB, Yada GK, Sarwar A. Feeding Practices and Early Childhood Caries: A Cross-Sectional Study of Preschool Children in Kanpur District India. Hindawi Publishing Corporation ISRN Dentistry 2013; ID 275193: 1-7.

7. Simin Z, Mohebbi SZ, Virtanen JI, Murtomaa H, Golpayegani MV, Vehkalahti MM. Mothers as facilitators of oral hygiene in early childhood. International J of Paediatric Dentistry 2008; 18: 48-55.

8. Oredugba F, Agbaje M, Ayedun O, Onajole A. Assessment of mothers' oral health knowledge: Towards Oral Health Promotion for Infants and Children. Health 2014; 6: 908-915.

9. Maharani Diah Ayu, Rahardjo Anton. Mothers' Dental Health Behaviors And Mother-Child's Dental Caries Experiences:Study of A Suburb Area In Indonesia. Makara, Kesehatan 2012: 16(2): 72-6.
10. Azevedo TD, Bezerra AC, De Toledo OA. Feeding Habits and Severe Early Childhood Caries in Brazilian Preschool Children. Pediatric Dentistry 2005; 27(1): 28-33.

11. Schroth Robert J, Halchuk Shelley, Star Leona. Prevalence and risk factors of caregiver reported Severe Early Childhood Caries in Manitoba First Nations children: results from the RHS Phase 2 (2008-2010). Int J Circumpolar Health 2013; 72: 21167: 1-10.

12. Ribeiro NME, Ribeiro MAS. Breastfeeding and Early Childhood Caries: a Critical Review. Jornal de Pediatria 2004; 80(5): S199-S210.

13. Subramaniam P, Prashanth P. Prevalence of Early Childhood Caries in 8-48 Month Old Preschool Children of Bangalore City, South India. Contemporary Clinical Dentistry 2012; 3(1): 15-21.

14. Losso EM, Tavares MC, Silva JY, Urban CA. Severe early childhood caries: An Integral Approach. Journal of Pediatrics (Rio J) 2009; 85(4): 295-300.

15. Kawashita Y, Kitamura M, Saito T. Early childhood caries. International Journal of Dentistry 2011; 2011: 7.

16. Sadeghi, Mostafa, Darakhshan, Bagherian. Is there an association between early childhood caries and serum iron and serum ferritin levels?. Dent Res J 2012; 9(3): 294-8.

17. Togoo Rafi A, M Zakirulla, Yaseen Syed Mohammed, VS Nasim, Al Qahtani Ali Robian, AlTurki Abdullah Ali. Cross-Sectional Study of Awareness and Knowledge of Causative Factors for Early Childhood Caries among Saudi Parents: A Step towards Prevention. International Journal of Health Sciences \& Research 2012; 2(3): 1-7.

18. Wigen TI, Wang NJ. Parental Influences on Dental Caries Development inPreschool Children. An Overview With Emphasis on Recent Norwegian Research. Norsk Epidemiologi 2012; 22(1): 13-9.

19. Naidu R, Nunn J, Forde M. Oral Healthcare of Preschool Children in Trinidad: a Qualitative Study of Parents and Caregivers. BMC Oral Health 2012; 12(27): 1-14.

20. Bozorgmehr E, Hajizamani A, Mohammadi TM. Oral Health Behavior of Parents as a Predictor of Oral Health Status of Their Children. ISRN Dentistry 2013; 2013: 1-5.

21. Bracksley S, Dickson SV, Anderson K, Gussy M. An Exploration of Mothers' Perceptions About Dental Health. Journal of Theory and Practice of Dental Public Health 2013; 1(1): 9-14.

22. De Jong Lenters M, Duijster D, Bruist M, Thijssen $\mathrm{J}$, de Ruiter C. The relationship between parenting, family interaction and childhood dental caries: A case-control study. Social Science \& Medicine 2014; 116: 49-55.

23. Suresh BS, Ravishankar TL, Chaitra TR, Mohapatra AK, Gupta V. Mother's knowledge about pre-school child's oral health. J Indian Soc Pedod Prev Dent 2010; 28: 282-7. 